\title{
Casuistry and Early Modern Spanish Literature: A Neglected Relationship
}

\author{
Marlen Bidwell-Steiner and Michael Scham
}

The title of this volume has an unspectacular, perhaps even ingenuous ring. And yet, it addresses complex relationships that were fertile with the production of cultural meaning. Early modern Spanish narrative encompasses an amazing variety of highly innovative literary forms. Labelling Don Quijote as the first modern novel has become a commonplace. Yet this is not the only original "Spanish" discourse. Although seemingly exclusively embedded in everyday life (and misery) of 16 th and 17 th century Spanish society, the genre of the picaresque immediately sweeps across Europe. Another case in point is the Spanish comedia as a hybrid dramatic form that transgresses Aristotelian norms for the sake of a changing public taste and need, as Lope de Vega elaborates in his Arte nuevo in 16o9. And even well-established genres like the Italian novella become thoroughly refashioned to reemerge in bespoke Spanish clothes. As is to be expected, the attempts to elucidate the extraordinary dynamics of literary and artistic cultures in the Siglo de Oro are myriad. One widely accepted hypothesis argues for the emergence of a specific "modern" subjectivity: a characteristic habitus that permitted reflection upon the tensions that were inherent to a society exposed to the ideologies of the Counter-Reformation, colonialist nation building and the fraught heritage of the three monotheistic cultures (Gumbrecht).

This is the period in which casuistry as a religious, legal, medical and literary practice gains momentum. Although its origins are conventionally associated with medieval penitential books and the practice of applying verdicts pronounced by church authorities in judging the severity of sins during confession, casuistry also has deep roots in legal and medical traditions, including Judaic and Islamic law and theology. Under the terms of the printing revolution, changing knowledge cultures spawn a sophisticated mingling of these threefold origins of casuistry.

The spread of casuistry in early modern Spain is vast, from the strict sense of resolving penitents' "cases of conscience" to broader political, economic, legal and scientific issues. Yet, perhaps owing to its image as a sophistical justification of suspect behavior and political expediency - a perception promoted by the Jansenist Pascal's famous denunciation of Jesuit "laxism" in his Lettres

(C) MARLEN BIDWELL-STEINER AND MICHAEL SCHAM, 2022 | DOI:10.1163/9789004506824_002 
provinciales (1657) -, Spanish casuistry has been understudied. Building on the recent attention to casuistry and theatre, this volume explores the interrelation between casuistry and different literary genres in Spain, such as the picaresque, the novella, novela sentimental, and the crónicas. The Querelle des Femmes tradition in late medieval sentimental novels, the casuistical debates of which would blossom in following centuries, allows us to bring out important considerations of gender in the literary works as well as in the culture more generally. As with Spanish theater, the novella develops around dilemmas relating to love and honor; and the flourishing of both literary forms coincides with crucial developments in moral philosophy.

Currently, a revival of casuistry is underway in international scholarship, a notable example being A Historical Approach to Casuistry (edited in 2019 by Carlo Ginzburg with Lucio Biasiori). With its connections to fundamental aspects of rhetoric and epistemological inquiry in various fields, the heritage of casuistry for what becomes labelled the Scientific Revolution is being given its due attention. But a systematic analysis of the impact of casuistical rhetoric on the emergence of highly successful and genuinely Spanish literary genres still is missing. This is all the more regrettable given Spain's distinct situation, which made it a breeding ground for early modern casuistry. To better understand casuistry's specific impact in Spain we briefly want to dwell on this development.

As Jonsen and Toulmin show in their most valuable study, Roman law had its own complicated trajectory from the College of Pontiffs to the Emperor Constantine (55), where jurisdiction became more legal than arbitral. One crucial figure in this heritage is the Roman lawyer, orator and philosopher Cicero, who "borrowed his cases [...] particularly from the literature of Stoicism and of its critics" (76). The Stoics coined the concept of "natural law," which Cicero refashioned under the precepts of Aristotelian Ethics.

For the context of this volume, it is important to point to Cicero's status as role model in early modern humanism. In the Italian Renaissance, Cicero virtually became christianized (especially through Petrarch) and his rhetorical and (to a lesser extent) his ethical writings were a must for the studia humanitatis. Rhetoric and moral philosophy thereby saw a revaluation in the curricula of the newly self-regulated universities in the mold of the one in Bologna. In this process rhetoric became the key discipline in resolving problems not belonging to the strictly theoretical realm of universal validity (i.e., mathematical 
logic). Thus, the particulars of natural law could be approached with Aristotle's enthymeme - an incomplete syllogism or reasoning by analogy. And all the more so with practical problems like ethics. The affinity between Aristotle's reasoning devices in his Rhetorics and his Topics already points to an elaborate casuistry, with the latter resembling the "Jesuit hexameter" (see below). It therefore provided an important model not only for Cicero but also for the Doctors of the Church, Augustine and Aquinas, two central figures for the Dominican friars. Founded by a Spaniard, this Order was especially involved in preaching and teaching. Dominicans also provided the most famous theologians at the University of Salamanca, who were the first to elaborate casuistry stricto sensu, as will be shown.

It is worth noting that in the ranks of Dominicans (as later also the Jesuits) there were many conversos. Some of them most certainly were acquainted with Halakhah, in the words of Jonsen and Toulmin "the casuistry of Rabbinic Judaism" (57). Sophisticated elaborations of Christian maxims certainly benefited from this cultural heritage. In terms of the development of imaginative literature, the Hebrew tradition might even be considered as more formative, as it focused on future cases and not - as the Christian tradition - on past ones. The pluralization of society and the change into an ever more scriptural culture entailed an increasing requirement to display all kinds of concrete everydaylife problems in clear argumentation. In Spain the distinct Catholic readjustment of society became crucial even prior to the Counter-Reformation, since it formed the core of the proto-national program of the Reconquista. Already in the 13th and 14th centuries the so-called (and highly disputed) convivencia came to its limits. With the expulsion of the Jews in 1492 and the accompanying mass conversions, the phenomenon of informing, or "snitching," on the one hand, and self-containment on the other hand led to an atmosphere of increasing social control. In such a situation, internalization and subjectivity are paramount (in this context, see Bidwell-Steiner, in this volume).

\section{$2 \quad$ Penitential Settings as Schools of Subjectivity}

This "inward turn" (a notion coined by Kahler) was fostered by the practice of penitence, which flourished in Catholic countries after the IV Lateran Council (1215) enacted yearly confessions on pain of excommunication. Friars urged the people to take advantage of this private sacramental talk with their confessor more often; later the Jesuits would excel in doing so (Maryks 2008: 19 sig.). In this development, penitential books flooded Europe to structure a penitent's narration, since the examination of conscience demanded a detailed depiction 
of every circumstance of sinful behavior following the famous questionnaire quis, quid, ubi, quibus auxiliis, cur, quomodo, quando (who, what, where, by which means, why, how, when), which will later be called the Jesuit hexameter.

Indeed, as will be shown, it was the Jesuits who adopted original approaches to earlier penitential guidelines by their Dominican colleagues to develop casuistry into a genuine discipline. Beside their early ministerial focus, Jesuits tended more and more toward tutoring and soon established the "largest educational system of the early modern world" (Maryks 2008: 4), given that their missionary activities included founding schools overseas. Their educational program combined scholastic premises with humanistic innovations. Thus, the Jesuit Ratio Studiorum was close to the Renaissance studia humanitatis. This included a blending of Ciceronian and Aristotelian rhetoric with an emphasis on controversies about difficult cases.

\section{3} A Short History of Spanish Casuistry

The reach of casuistry in early modern Spain expanded dramatically, from the strict sense of resolving penitents' cases of conscience to broader political, economic, jurisprudential and scientific issues. Casuists became prominent educators, economists and political advisers, and their methods were adopted in numerous fields.

The Dominican thinkers Francisco de Vitoria (c.1483-1546), Domingo de Soto (1494-1560) and Bartolomé de Medina (1527-1581) were key members of the "School of Salamanca," which modernized economic thought and developed international law. Their ethical casuistry would be adopted and further elaborated by Jesuits such as Luis de Molina (1528-1581). In the realm of skepticism in medicine and natural philosophy, Francisco Sánchez (1551-1623) is joined by figures like Gómez Pereira (1500-1558?), who developed a strategy of systematic doubt informed by casuistical heuristics (Bidwell-Steiner 2017). Humanists acknowledged the challenge of epistemological relativism and sought to overcome it by considering multiple perspectives, for example by "arguing in utramque partem (on both sides of the question)" in order "to arrive at what they called approximate knowledge, or probable truth" (Kallendorf 2007: 192). Harald Maihold insits quite rightly on the need of considering fictional transgressions within the contemporaneous discussions of the above-mentioned moralists and their accentuations of specific vices (Maihold $363^{-} 365$ ).

The Jesuit involvement in education, politics and economics contributed to the rise of a new notion of the subject. Their casuistry is part of "an important shift that characterized the transition from medieval ethics into a modern 
mentality characterized by a higher degree of subjectivity, responsibility and interiority" (Maryks 2008: 117-18). Put this way, early modern casuistry can be understood as a re-negotiation or even reversal of what Jesús Velasco in his analysis of the Siete Partidas identifies as the dialectics between living and dead voices (Velasco 25-52): while medieval law theorists try to transform the living voice in legal texts in the process of creating a persona authentica, early modern casuists emphasize the singularity of lived experience and, as such, challenge the time-transcending validity of the written text.

Such developments are connected to the emergence of Spain as the paradigmatic proto-nationalist Counter-Reformation, imperial and colonialist state with a complex administrative organization. The administration of the colonies raises all kind of ethical questions that could only be dealt with in terms of casuistical methodologies, bringing conversant principles to new phenomena. The most prominent task here is the disputation about the status of autochthonous peoples, most famously in Francisco de Vitoria's De Indis (1532) and in Bartolomé de Las Casas' Historia de las Indias (1552). The "unsought moral relativism" that resulted from the encounter with the New World (cf. Childers) posed profound challenges to established values and the understanding of notions such as humanity and civilization and its customs (see Cárdenas Bunsen, in this volume).

It was a literary scholar who gave us what is still the most valid in-depth definition for "the casus" - be it moral, juridical or medical: "The special character of the case lies in the fact that it asks the question, but cannot give the answer; that it imposes the duty of judgement upon us, but does not itself contain the judgement - what becomes manifest in it is the act of weighing [Wägen], but not the result of the weighing" (Jolles 350 [191]). In other words: at the core of casuistry is a dilemma, a "tension [...] between norms and exceptions. They need each other; they fuel each other," as Carlo Ginzburg puts it in a recent volume on the outreach of casuistry in different historical fields of knowledge (Ginzburg xii). Casuistry links the contingent, the real and the abstract in a graspable form.

Casuistry at its simplest, e.g. in homily, uses cases as imaginings for an abstract normative principle. As J. Allan Mitchell put it, "Casuistry is a diagnostic technique that enables the practitioner to make sense of new cases and unfamiliar circumstances by drawing on analogies with the old and familiar" (24). In its origin, this discursive form is akin to exemplarity. Yet casuistry never 
creates a unidimensional relationship between case and principle. While example provides a model for behavior, and thus forms the basis for articulating a rule that may be followed in similar circumstances, casuistry takes as point of departure past examples and precept, which both serve as a guide and are tested and modified in the new circumstances.

The medieval notion of the example's authoritative applicability to lived experience, and of the validity of ideal models of behavior in general, was increasingly called into question, both liberating and placing burdens of responsibility on the individual subject. Scholars like Hampton, Stierle and Rigolot have made much of the early modern "crisis of exemplarity," and a turn toward open-ended dialogue and even individual rumination. We emphasize how this entire discussion can be reframed from the perspective of casuistry, particularly with the subjective consultation of conscience in probabilism. This doctrine was developed by the Dominican Bartolomé de Medina and consisted in the idea that it is licit to follow an opinion even though the contrary one is more probable - that is, advocated by majority opinion (Medina I-II, q. 19). Its appeal seems to rest upon resistance to a schematic or statistical plausibility. Such an openness to the "benefit of doubt" allows for the exercise of individual conscience. As the contributions in this volume illustrate, the literary notion of verisimilitude, and the poetic freedom it affords, has ties with the development of probabilism. Casuistry can be seen to arise amidst the crisis of exemplarity, just as early modern narrative reframes the exemplary tradition. The richly diverse background of such narratives extends back to this tradition and to the literatura sapiencial of the Middle Ages, from Petrus Alphonsi's Disciplina Clericalis (12th Century), to El Sendebar (circa 1250), Calila e Dimna (circa 1250), and in some ways culminating in Juan Manuel's El conde Lucanor (1350). These works are also crucial to casuistry, as they present and attempt to make sense of myriad dilemmas and circumstances, many coming from eastern narrative and folkloric traditions. When the Italian Renaissance novella took over this heritage, it often jauntily violated the exemplary function of narration. However, with the Counter-Reformation such playfulness became suspicious. This is where casuistical taxonomy and its versatility in "finding" an ethical solution provides a loophole. The lack of clear-cut didacticism can be cast as a necessary subtlety of investigation (see Albert, in this volume). In this respect Cervantes' status as the creator of a distinctly Spanish version of the novella's claim on exemplarity is justified: the gap between a protagonist's failure and poetic justice is to be bridged by the interpretative probabilism of the individual reader. 
To sum up: original exemplary narratives attempt to illustrate laws and precepts with the narrated events, which might edify the reader with rules to live by. Casuistry saturated this narrative tradition with a multiplicity of possible solutions, thereby extending the narrative horizon and ethical competencies of the early modern subject.

To be sure, early forms of casuistry did resemble exemplarity. The tuciorismo (or "tutiorism," the decree to follow the "safest path") expounded in Juan Polanco's Directorium breve (1560), similarly promoted the distillation of circumstance to one clear rule that, in the interest of saving one's soul, must be heeded (cf. Braun and Vallance). Bartolomé de Medina's (Breve instrucción de cómo se ha de administrar el sacramento de la penitencia 1579) and Francisco de Toledo's (Instrucción de sacerdotes 1596) insistence on probabilismo brought accusations (as mentioned, most famously from Pascal) of laxism and political expediency. In practice, such sophistry undoubtedly took place; but the present volume reflects how figures such as Medina and Toledo were responding in a sincere manner to momentous shifts of their epoch.

As casuistry developed from its scholastic roots and the authoritative norms of tutiorism in the Middle Ages to the expansion of agency in full-blown probabilism in the 16th century, it extended - as noted - well beyond the confessional, becoming increasingly relevant in a progressively more literate culture. The scholastic method was not so much supplanted as it was integrated with the rhetorical, epistemological and civic concerns of humanism.

\section{$5 \quad$ Casuistry Permeating Different Fields of Knowledge}

In the words of Henry Sullivan, casuistry was "an offshoot of theology that became a method of mind" (51). It forms a sort of epistemology, one that registers the destabilizing yet also liberating experience of an ever more contingent world. With its testing of precepts amidst the vagaries of circumstance, casuistry becomes a mode of imaginative argumentation and inquiry. Not only does it permeate jurisprudence, economy, theology and medicine; casuistry evolves hand in hand with skepticism, nominalism, a renewed interest in rhetoric, the so-called crisis of exemplarity, an emerging awareness of subjectivity and the limits of reason, a defense of free will, and the rise of absolutism and Reason of State. With regard to politics, Anthony Cascardi notes how Machiavelli (a figure much reviled while unquestionably also influential in early modern Spain) called for "a new kind of discourse - not to the discourse of the philosophers, but to a rhetoric of examples and commentary designed 
to illuminate what is most effective" (Cascardi 16). Casuistry in medicine and natural philosophy helps us better understand affect, a significant aspect of the literary works under question. To take the concerns of many prominent theories of the novel, we can say that the arc of casuistry, especially in the bloom of probabilism, points toward modernity.

The present volume explores the discourse and methodologies of casuistry in early modern Spanish literature. In doing so, it proposes to fill a significant gap in Peninsular literary studies. Jolles' morphological analyses already indicate that the casuistical Sprachgebärde ('linguistic gesture') is an important prerequisite for the novella. This is exactly our point of departure: to better understand how the alleged (pre)modern subjectivity is fashioned, this volume will trace the specific "balancing" (Jolles) of casuistry in different narrative genres of the Peninsula. Yet, we want to emphasize that we do not claim an exclusive appropriation of casuistical inquiry to imaginative literature. We rather deem casuistry as a mindset that captures and at the same time informs various modes of communication. The effect of the transition from oral to print culture on argumentative structuring and dissemination is also given attention (see Bidwell-Steiner, Scham, Traninger in this volume). In this spirit literary narratives also feed back into Jesuit moral reasonings.

In the realm of imaginative literature, casuistry has primarily been considered in light of the comedia by scholars like Kallendorf and Gómez Canseco. However, as Josephine Donovan suggested, one might also turn to casuistry to provide an alternative history of prose narrative - or, at least, a significant modification of it. Recalling Ortega y Gasset's (1984) celebrated assertion that the modern novel, initiated by Don Quijote, discovers that individuals are comprised of self and circumstance ("Yo soy yo y mi circunstancia"), the contemporaneous flourishing of casuistry is indeed noteworthy. The contributors to this volume show how different genres developed both from and with casuistry, from the narrative and rhetorical strategies deployed, to the very source material upon which they draw. We do not mean simply to point out the striking parallels between the concerns of casuistry and those reflected in the innovations of early modern imaginative literature. Specific instances of influence and source appropriation are also revealed and examined. Our call for a reappraisal of casuistry in early modern Spain is intended to provoke a rethinking of literary history, including the very rise of what we have come to call the modern novel. 
As mentioned, the relative lack of attention to Spanish casuistry perhaps owes to its image as a sophistical justification of suspect behavior and political expediency. In Pascal's influential denunciation of Jesuit "laxism" in his Lettres provinciales (1657), many of the primary Spanish thinkers, including Molina, Suárez, Valencia, Vásquez and Escobar, are accused of a pernicious duplicity: "qu'ils couvrent leur prudence humaine et politique du prétexte d'une prudence divine et chrétienne; comme si la foi, et la tradition qui la maintient, n'etait pas toujours une et invariable dans tous les temps et dans tous les lieux" (Cinquiéme lettre). As Ginzburg recently showed, the making of Pascal's famous diatribe is in itself a sort of mystery plot, for it relies on other texts of his Port Royal circle of friends, with Charles Perrault's brother Nicolas as mastermind: "Pascal seems to have used Perrault's work-in-progress to find his way in the maze of casuistical literature" (Ginzburg 289). And the resulting mockery would be taken up by famous French authors like Molière.

Countering the black legend following the Port Royal circle, Caro Baroja pointed out that the Jesuits in fact practiced a range of casuistry, developing from a rigorist tutiorism, which sought the sole correct authority to which one then unquestioningly submits, to the individual responsibility and agency of probabilism, in which various authorities are examined, and the final decision taken based on particular circumstance and "conscience." Far from a capricious rationalization, probabilism incorporates the Ciceronian premise that absolute certainty is impossible, that one must always deal with probabilities, and that the probabilities are contingent upon circumstances.

The curriculum (ratio studorium) of the Jesuit colegios, with their weekly discussion of doubtful cases (casos dudosos) and arguments in utramque partem, also included an emphasis on the examination of conscience, which in turn extended to political advisers who dealt with the conscience of the king and issues of Reason of State. Such inwardness and acknowledgement of subjectivity - bordering on a recognition of the relativity of truth claims resonated with the revival of classical skepticism. These psychological and epistemological developments found fertile ground in the context of the vertiginous flow of knowledge and goods from the New World, religious schisms, scientific discovery, and unprecedented access to and study of ancient texts. On the foundations of Artistotle's assertion that we must deal with claims that are true "for the most part" (Ethics), to Cicero's injunction that things are not true or untrue, but rather more or less probable (De Officiis), to the radical skepticism of Francisco Sánchez' Quod nihil scitur (1581), the casuists' 
emphasis on circumstance, individual experience, and gradations of certainty and uncertainty formed part of the more general revolution of consciousness in the epoch. It is the same revolution, often couched in the now highly recognizable terms of modernity, which we associate with novelistic discourse.

\section{The "Poetics" of Casuistry}

All of this underlines the relationship between casuistry and the theories of verisimilitude and narrative cohesiveness elaborated by the Neo-Aristotelians, not to mention the concerns with the perils of narration emphasized by the Platonists, as well as humanists such as Juan Luis Vives. Along these lines, Roberto González-Echevarría goes as far as to claim that "[c]asuistry entails a whole program of representation that is more detailed, technical, and stringent than the one inherited from traditional literary sources and practices" (31). As Donovan and others have suggested, the often sensational "cases" presented in the thousands of pages of manuals in the period (many re-issued in several editions, and published in Spanish rather than Latin to reach as wide an audience as possible) may well have served as a rich vein of material for artistic elaboration in contemporary narrative fiction. Del Río Parra aptly points to the vast range of situations recorded in the casos as comprising an intrahistoria, the vital substrate of human experience in early modern Spain. As Julio Caro Baroja put it, casuistry opens up "un mundo de oscurísimas realidades psicológicas y ... la enorme variedad de modos de comportarse los hombres en unas sociedades dadas" (525). González-Echevarría makes a similar case for the contemporary legal record, which he rightly considers a field of mutual pollination with casuistry.

The famous Jesuit "hexameter" indicates the casuist's interest in fully understanding the context of an action. To take an example common in picaresque novels (see below), we might apply the hexameter to a transgression against the Seventh Commandment (No hurtarás): Who stole, what was stolen, why, by what means, when? There is a concern with judging according to the context in which the event occurs, and observing the Ciceronian injunction to assess the probable according to factors such as person, place, customs, laws, and the times (Maryks 2016). Factors relating to gender, age, intention, or even mitigating states such as anger or inebriation could be taken into account. As Azpilcueta warned, the confessor must be tactful in questioning the penitent, lest new and pernicious ideas be transmitted: "y no [preguntar] de los pecados ocultos que los muy maliciosos han inventado, sino tan cauta y disimuladamente, y por tales circunloquios que si los hizo los diga, y si no los hizo, no los 
aprenda" (Manual de confessores y penitentes 1554). As Bartolomé de Medina noted, the dynamic was also precarious for the confessor himself: "que muchas vezes estos tales [confesores] por hablar con ellas, sienten ciertas titilaciones y humedades sin quererlo" (Breve instruccion de como se ha de administrar el Sacramento de la Penitencia 1580). Needless to say, the Commandment in question here is the Sixth, which occasioned myriad sub-categories and the application of specialized vocabulary. The manuales even contained advice to the penitents regarding effective recounting of their actions, including what sorts of detail were essential, and which could be omitted (see Scham, in this volume). Despite the nuanced terminology, gradations, categories and prurient interest inspired by transgressions of the Sixth Commandment, Teófanes Egido has pointed out that the Seventh actually occupied the casuists to a greater degree. As it was conceived as pertaining to theft and justice more broadly, no hurtarás was also considered in light of the urgent early modern debates about the permissibility of charging interest, or setting proper prices and salaries, among other matters pertaining to economics and business. In the context of increasingly international trade and a nascent mercantilism, ${ }^{1}$ the traditional prohibitions against usury were no longer in step with the times. With its exploration of varieties of leisure (of nobility and of rogues), of work, and of thievery and deception in all its forms, the emerging picaresque genre engaged the very present concerns of the casuists.

\section{Genres as Cases in Point}

A focus on picaresque works comprises a large part of this volume. Already the famous precursor of the genre, Fernando de Rojas' La Celestina, points to casuistical reasoning as a decisive element of the discourse's referential function. In "Justice Blindfolded: Law and Crime in La Celestina," MARLEN BIDWELL-STEINER examines the shifting value systems of love, sex and honor as they relate to the peculiar "death cases" represented in the work, calling for a reassessment of the notions of crime and punishment pondered by the intellectual circle of the law student Fernando de Rojas. As she shows, the tensions between different legal conceptions allow for multifaceted characters, which invite the readers to subjective interpretations. In the actual picaresque "prototype", this trend becomes constitutive of the genre: Lazarillo de Tormes negogiates a "caso" that remains pending until the very end of the protagonist's life-writing.

1 A field that has been elaborated by Cavillac 1994. 
EDWARD FRIEDMAN's detailed revisiting in "Artful Rhetoric: The Case of Lázaro de Tormes" illustrates the circumstances and rhetorical stances that are in play to make sense not just of the caso referenced in the prologue (supposedly having to do with Lázaro's wife and the archpriest), but, perhaps more importantly, of his entire life trajectory, with its qualified social ascendance and compromising behavior. Along with an incisive casuistry of honor accompanied by the mitigating leitmotif of hunger, Friedman shows how Lazarillo de Tormes delivers a probabilistic examination of case morality: "The assessment of ethical points and, therein, issues of right and wrong are supremely indeterminate, prompting dialogue from many vantage points." (see p. 54 in this volume). Given the prominence of the text, one is inclined to hypothesize about its impact on moral casuistry. From the caso that forms the narrative premise of Lazarillo de Tormes, to the derisive parody of ethical rumination in La picara Justina, the picaresque is permeated by legalistic and casuistical discourse. As Michel Cavillac has argued in numerous recent studies, Mateo Alemán's picaresque masterpiece not only contains a sustained examination of economic casuistry, but also culminates in the dramatization of a central concern of the foremost political casuists, who were strenuously trying to come to terms with Machiavelli's The Prince: the very notion of Reason of State (Cavillac 2010, 2007). In the present volume, DAVID ALVAREZ ROBLIN examines the tenuous and - from a jurisprudential perspective, foundational - relationship between revenge and just punishment on two fundamental levels: that of character within the narrative, as the eponymous anti-hero of Guzmán de Alfarache attempts to redress his grievances without falling into the base behaviour he purports to critique in his moralizing digressions; and that of the author himself, as Mateo Alemán confronts the apocryphal Guzmán de Alfarache in his own "authentic" second part (1604). The result is a fascinating look at the casuistry of "street crime" as well as that which might distinguish literary theft from licit appropriation - that is, the casuistry of artistic creation. As intimated above, La Pícara Justina scoffs at Guzmán's “conversion," mocking the casuistical discourse of his narration. DAVID MAÑERO LOZANO'S contribution to the volume examines how López de Úbeda presents a sequence of cases that are inimical to the moral principles expressed, resulting in a parody that calls into question the picaresque fictions' edifying, doctrinal pretense.

An almost complementary narration of pre-modern subjectivity is elucidated by ANITA TRANINGER in "The Exploration of Circumstance: Casuistry and the Emergence of the Novela Bizantina in Alonso Núñez de Reinoso's Historia de los amores de Clareo y Florisea, y de los trabajos de Ysea (1552)." From a comparative angle, Traninger shows how the experiences of displacement and destitution represented in the novela bizantina generate a staging 
of applied ethics. Reinoso's "ego-document" has a female narrator, a gender switch that brings innovations to the traditional, putatively "conservative" representational mode of romance. Here we would emphasize the substantial role casuistry plays in the emergence of new literary forms and the transformation of existing ones, as they both critique established genres and seek out novel ways to make sense of a perplexing world.

If the picaresque arises as a "counter genre" (to use Claudio Guillén's term), creating something new in opposition to traditional romance forms, the novella appropriated and innovated promiscuously, facilitating the cross-pollination that gave rise to the novel. In "The Lawyers' Tales: Legal Casuistics and the Spanish Golden Age Novella (Cristóbal Suárez de Figueroa, Alonso de Castillo Solórzano)," MECHTHILD ALBERT delves into the variegated field of the misceláneas and short narratives, revealing the casuistical structures at work in two of the major figures of the genre. The comparison fleshes out the differences between a rather traditional use of exemplarity and a more casuistical one. With particular attention to legal casuistry, Albert's essay resonates with the preceding contribution of Bidwell-Steiner.

Since casuistry calls into question the very applicability of example and precept to the disorderliness of the everyday world, and is a major force behind the rising awareness of the reductive insufficiency of established modes of representation, argument and explanation, one is compelled to examine the dramatization of such disjunctions in Cervantes. While Don Quijote is a recurring touchstone throughout the volume, in "Comic Casuistry and Common Sense: Sancho Panza's Governorship," M ICHAEL SCHAM contends that Sancho Panza, as Governor of Barataria, embodies many aspects of the ideal ruler as set out in contemporary casuistical tracts on right rule and Reason of State. Governor Sancho's improvisations and inimical linguistic usage, in turn, provide an illustration of the casuistical process in the emergence of novelistic character.

With the discovery of the New World, the search for applicable precept becomes as confounding as it is urgent. JOSÉ CÁRDENAS BUNSEN analyses the renewed scrutiny of theological tenets and canon law as figures such as Bartolomé de las Casas attempted to come to terms with the practice of human sacrifice in the Americas. In "Opinion, Idolatry, and Indigenous Consciousness: Bartolomé de las Casas' Approach to Human Sacrifice," Cárdenas Bunsen brings early modern ethnography and historical writings under the purview of casuistry. In his fascinating reconstruction of Las Casas' insistence on a deeply ethical awareness of the indigenous subjects in the Americas, he offers a valuable contribution to early modern Postcolonial Studies.

Circling back to the genre that first attracted the attention of serious casuistry studies relating to Peninsular literature, HILAIRE KALLEndorf assesses 
the current state of casuistry scholarship in the comedia, with a focus on "Staging Penance: Scenes of Sacramental Confession in early modern Spanish Drama." Drawing upon the rich quarry of Jesuit drama dealing with the casuistry of conscience, Kallendorf reveals a remarkable range of plays depicting successful and failed confessions. A further type of "case study" is thus shown to be at the heart of innovations in early modern Spanish poetics. In sum, this volume significantly develops what Childers termed the "empty lot" of Spanish casuistry studies, while pointing the way to new areas of inquiry.

In conclusion, the relationship between casuistical argumentation and literary invention is polyvalent. The nuanced scrutinization of circumstance corresponds to complex narrations and multifaceted characters. As many of the contributors to this volume show, a result is often the creation of a "casuistical reader," who must attempt to resolve lingering dissonances. Not least, the numerous epigones of successful early modern texts prove that such an openness enhances the reader's ability to form their own imaginary cases (as, for example, David Álvarez Roblin shows with respect to Mateo Alemán's imitator and "rival"). Yet, the subtlety of high casuistry also provides cover for unorthodox and even subversive approaches, since the pattern of an exemplary claim can be superimposed on a plot rife with vicissitude and complicated circumstances, often compounded with the rhetorical register of irony.

The different essays gathered here follow these ingredients as they enter the crucible of early modern discovery, crisis and innovation. In addition to a renewed appreciation of the centrality of casuistry in early modern Spanish culture and literary production, this volume offers an original perspective on the development of early prose narrative.

\section{Works Cited}

Bidwell-Steiner, Marlen. Das Grenzwesen Mensch: vormoderne Naturphilosophie und Literatur im Dialog mit postmoderner Gendertheorie. Berlin: de Gruyter, 2017.

Braun. H.E. and E. Vallance (eds.). Contexts of Conscience in Early Modern Europe, $1500-$ 1700. Basingstoke and New York: Palgrave-Macmillan, 2004.

Caro Baroja, Julio. Las formas complejas de la vida religiosa: religión, sociedad y carácter en la España de los siglos XVI y XVII. Madrid: Akal, 1978.

Cascardi, Anthony J. Cervantes, Literature and the Discourse of Politics. Toronto: University of Toronto Press, 2016.

Cavillac, Michel. Guzmán de Alfarache y la novela moderna. Madrid: Casa de Velázquez, 2010. 
Cavillac, Michel. "Atalayisme” et picaresque: la vérité proscrite. Bordeaux: Presses Univiersitaires de Bordeaux, 2007.

Cavillac, Michel. Pícaros y mercaderes en el Guzmán de Alfarache. Granada: Universidad de Granada, 1994.

Childers, William. "Hispanic Casuistry Studies: Room to Grow." Hispanic Review 79.2 (2011): 317-326.

Del Río Parra, Elena. Cartografías de conciencia española en la Edad de Oro. Mexico: Fondo de Cultura Económica, 2008.

Donovan, Josephine. Women and the Rise of the Novel, 1405-1726. NY: St. Martin's, 1999. Egido, Teófanes. "Los casos de conciencia y la conciencia de los casos." Las Españas que (no) pudieron ser: herejías, exilios y otras conciencias (s. XVI-XX). In Las Españas que (no) pudieron ser. Ed. Manuel Peña Díaz. Huelva: Universidad de Huelva, 2oog: 93-113.

Ginzburg, Carlo. "Preface". A Historical Approach to Casuistry. Norms and Exceptions in a Comparative Perspective. Eds. Carlo Ginzburg and Lucio Biasiori. London/New York: Bloomsbury, 2019: xi-xx.

González Echevarría, Roberto. Love and the Law in Cervantes. New Haven: Yale UP, 2005.

Grice-Hutchinson, Marjorie. "The concept of the School of Salamanca: Its Origins and Development." Revista de historia económica 7 (1989): 24-35.

Hampton, Timothy. Writing from History: The Rhetoric of Exemplarity in Renaissance Literature. Ithaca: Cornell UP, 199 o.

Ife, B.W. Reading and Fiction in Golden-Age Spain: a Platonist Critique and Some Picaresque Replies. Cambridge: UP, 1985.

Jolles, André. Einfache Formen. Legende, Sage, Mythe, Rätsel, Spruch, Kasus, Memorabile, Märchen, Witz. Berlin: de Gruyter, 2017 (Saale: Niemeyer 1930).

Jolles, André. Simple Forms. Trans. J. Schwartz. London/New York: Verso, 2017.

Kahler, Erich. The Inward Turn of Narrative. Princeton: University Press, 1973.

Kallendorf, Hilaire. Conscience on Stage: The Comedia as Casuistry in Early Modern Spain. Toronto: University of Toronto Press, 2007.

Maihold, Harald. "Ich Sündige, Also Bin Ich." Zeitschrift des Max-Planck-Instituts für Europäische Rechtsgeschichte 22 (2014): 363-65.

Maryks, Robert A. "Rhetorical Veri-similitudo:Cicero, Probabilism and Jesuit Casuistry." Traditions of Eloquence: The Jesuits and Modern Rhetorical Studies. Eds. Cinthia Gannett and John C. Brereton. Fordham University, 2016: 6o-72.

Maryks, Robert A. Saint Cicero and the Jesuits: The Influence of the Liberal Arts on the Adoption of Moral Probabilism (Catholic Christendom, 1300-1700). Aldershot: Ashgate, 2008.

Melé, Domènec. "Early Business Ethics in Spain: The Salamanca School (1526-1614)." Journal of Business Ethics 22.3 (1999): 175-189. 
Mitchell, J. Allan. "Rhetorical Reason: Cases, Conscience, and Circumstances." Ethics and Exemplary Narrative in Chaucer and Gower, 33, Boydell and Brewer, 2004: 22-35. Ortega y Gasset, José. Meditaciones Del Quijote. Ed. Julian Marias. Madrid: Catedra, 1984.

Pascal, Blaise. Les lettres pronvinciales. Paris: Gallimard, 1987.

Rigolot, François. "Problematizing Renaissance Exemplarity: The Inward Turn of Dialogue from Petrarch to Montaigne." Printed Voices: The Renaissance Culture of Dialogue. Eds. Jean-François Vallée and Dorotea Heitsch. Toronto: University of Toronto Press, 2004: 3-24.

Stierle, Karlheinz. "Three Moments in the Crisis of Exemplarity: Boccaccio-Petrarch, Montaigne, and Cervantes." Journal of the History of Ideas 59.4 (1998): 581-595.

Sullivan, Henry. "Moral Probabilism and Casuistry in Spain during the Counter Reformation." Tirso de Molina and the Drama of the Counter Reformation. Amsterdam: Ropodi, 1976: 40-51.

Velasco, Jesús R. Dead Voice: Law, Philosophy, and Fiction in the Iberian Middle Ages. Philadelphia: University of Pennsylvania Press, 2019. 